\title{
SITE QUALITY ESTIMATIONS BASED ON THE GENERALIZED ALGEBRAIC DIFFERENCE APPROACH: A CASE STUDY IN ÇANKIRI FORESTS ${ }^{1}$
}

\author{
Ugur Akbas² and Muammer SENYURT ${ }^{2 *}$
}

\begin{abstract}
${ }^{1}$ Received on 20.04.2018 accepted for publication on 09.07.2018.
${ }^{2}$ Cankiri Karatekin University, Turquia. E-mail: <muammer1907@gmail.com> and <ugurakbas44@gmail.com>. *Corresponding author.

ABSTRACT - In this study, it is aimed that the dynamic site index models were developed for Crimean Pine stands in Sarikaya-Cankiri forests located in middle northern Turkey. The data for this study are 153 sample trees obtained from the Crimean Pine stands. In modeling relationships between height and age of dominant or co-dominant trees, some dynamic site index equations such as Chapman-Richards (M1, M2, M3), Lundqvist (M4 and M6), Hossfeld (M5), Weibull (M7) and Schumacher (M8) based on the Generalized Algebraic Difference Approach (GADA) were used. The estimations for these eight-dynamic site index model parameters with well as various statistical values were obtained using the nonlinear regression technique. Among these equations, the Chapman-Richards's equation, M3, was determined to be the most successful model, with accounted for $89.03 \%$ of the total variance in height-age relationships with MSE: 1.7633, RMSE: 1.3279, SSE: 1165.6, Bias: -0.0380. After determination of the best predictive model, ARMA $(1,1)$ autoregressive prediction technique was used to account autocorrelation problems for time-series height measurements. When ARMA autoregressive prediction technique was applied to the Chapman-Richards function for solving autocorrelation problem, these success statistics were improved as SSE: 868.7, MSE: 1.3183, RMSE: 1.1482 , Bias: $-0.06369, \mathrm{R}^{2}: 0.918$. Also, Durbin-Watson statistics displayed that autocorrelation problem was solved by the use of ARMA autoregressive prediction technique; $\mathrm{DW}$ test value $=1.99, \mathrm{DW}<\mathrm{P}=0.5622, \mathrm{DW}>\mathrm{P}=0.4378$. The dynamic site index model that was developed has provided results compatible with the growth characteristics expected in the modeling of height-age relations, such as polymorphism, multiple asymptote, and base-age invariance.
\end{abstract}

Keywords: Dynamic site index model; Autoregressive modeling; Crimean pine

\section{ESTIMATIVAS DA QUALIDADE DO SITE COM BASE NA ABORDAGEM GENERALIZADA DA DIFERENÇA DA ALGEBRAIA: UM ESTUDO DE CASO NAS FLORESTAS DE CANKIRI}

\begin{abstract}
RESUMO - Neste estudo, objetiva-se que os modelos de indices de sítios dinâmicos foram desenvolvidos para os estandes do Pinus da Criméia nas florestas Sarikaya-Cankiri localizadas no meio do norte da Turquia. Os dados para este estudo são 153 árvores de amostra obtidas dos estandes do Pinus da Criméia. Na modelagem de relações entre altura e idade de árvores dominantes ou co-dominantes, algumas equações de indices de sítios dinâmicos como Chapman-Richards (M1, M2, M3), Lundqvist (M4 e M6), Hossfeld (M5), Weibull (M7) e Schumacher (M8) baseado na Abordagem Generalizada da Diferença Algébrica (GADA) foi utilizada. As estimativas para estes parâmetros do modelo de índice de oito locais dinâmicos, bem como vários valores estatísticos, foram obtidas utilizando a técnica de regressão não linear. Entre essas equações, a equação de Chapman-Richards, M3, foi determinada como sendo o modelo mais bem-sucedido, representando 89,03\% da variância total nas relações altura-idade com MSE: 1,7633, RMSE: 1,3279, SSE: 1165,6, Viés:-0,0380. Após a determinação do melhor modelo preditivo, a técnica de predição autoregressiva ARMA $(1,1)$ foi utilizada para contabilizar os problemas de autocorrelação para as medidas de altura das séries temporais. Quando a técnica de previsão autorregressiva ARMA foi aplicada à função de Chapman-Richards para resolver o problema de autocorrelação, estas estatísticas de sucesso foram melhoradas como SSE: 868.7, MSE: 1.3183, RMSE: 1.1482, Bias: -0.06369, R2: 0.918. Além disso, as estatísticas de Durbin-Watson mostraram que o problema de autocorrelação foi resolvido pelo uso da técnica de previsão autorregressiva ARMA; Valor do teste $D W=1,99, D W<P=0,5622, D W>P=0,4378$. O modelo de indice de sitio dinâmico desenvolvido forneceu resultados compativeis com as características de crescimento esperadas na modelagem das relações altura-idade, como polimorfismo, assíntota múltipla e invariância da idade-base.
\end{abstract}

Palavras-Chave: Modelo de índice de site dinâmico; Modelagem autoregressiva; Pinheiro da Criméia 


\section{INTRODUCTION}

One of the main factors that affect the growth and yields of trees is the site quality, which is also known as the site index (Carmean, 1972). Differences in site quality considerably affected forest applications such as silviculture, management practices, protection, etc. The forest site quality is a factor that should be specifically considered in forestry applications (Elfving and Kiviste, 1997). In this respect, one of the main tasks for forest management should be to determine the forest site quality and to also classify forests according to site index (Clutter et al., 1983).

Since the 1700 s, the forest site quality has been the subject of many studies. The first studies on this subject primarily used medium height trees being as site quality index and the law regarding the classification based on the medium height trees was designated as the Eichorn Law (Kalýpsýz, 1998). While studies performed during these initial years preferred using medium height trees to determine the site index, it was also observed that due the removal of shorter trees in thinning practices, the medium height values began to mathematically increase. However, as distinct from this feature of medium height, the upper height, which is calculated on the heights of the dominant trees in the upper layer, is calculated within the scope of silvicultural practices by using uncut trees that have not been handled or manipulated. In this context, the dominant height is calculated as the mean height of the number of trees in the upper layer of the sampled area as determined by using the 100 Tree Method (according to Hart), or as the height value of the stand mean for the trees with the thickest diameter (according to Assmann). The dominant height is accepted as an indicator of site index values and is nowadays used as an indication of site quality (Stage, 1963; Curtis et al., 1974; Monserud, 1984).

When developing site index tables, it is mainly expected that the site curves meet some main characteristics relating to various growth laws (Cieszewski, 1999). The growth laws in question have been described by Cieszewski $(2002,2003,2004)$ as (i) Polymorphism, (ii) Multiple Asymptote, (iii) the attributes relating the time durations for reaching maximum height, and (iv) the base-age invariance (Diéguez-Aranda et al., 2006; Cieszewski et al., 2007). In classical methods, the site index tables are developed according to a standard age that is selected at the beginning by the researcher designing the table (Cieszewski, 1999). On the other hand, the classical methods tend to be somewhat limited when researchers wish to use an age other than the standard ages. Site index models developed with classical methods are as a consequence dependent on a certain standard age. This age-dependence of classical methods is referred to as that standard age variance (Cieszewski, 1999). To solve the problems of the classical method in meeting the requirements of all relevant laws - and specially to remedy its problems with regards to the standard age variance - the Algebraic Difference Approach (ADA) was developed in by Bailey and Clutter (1974). In the ensuing years, Cieszewski and Bailey (2000) developed the Generalized Algebraic Difference Approach (GADA), a more advanced application of the ADA. In addition to having been developed as a solution to the standard age variance, GADA is also quite effective in satisfying the requirements of other laws and principles. In this respect, GADA-based site index models, which have a somewhat complex modeling structure, are not dependent on a certain standard age and are relatively successful in meeting the requirements of the laws regarding multiple asymptotes, polymorphism and maximum height increase. The dynamic site index models derived by GADA have shown better and more successful properties than the fixed base-age site index models in many recent studies, e. g. Rodríguez-Carrillo et al., (2015); Tewari et al. (2014); López-Sánchez et al. (2015), Ribeiro et al. (2016), Liziniewicz et al. (2016); Seki and Sakýcý (2017); Pyo (2017); Nigh (2017), Kahriman et al. (2018); Hirigoyen et al. (2018). Therefore, GADAbased dynamic site index models have been used frequently for modeling dominant height-age growth and developing site index curves in forest literature.

Crimean pine (Pinus nigra Arnold. subsp. pallasiana (lamb.) holmboe) is one of the most economically and ecologically significant forest tree species for Turkey with its appreciated wood for many profitable uses. In Turkey, Crimean Pine forests cover $4,244,921$ ha and compose the nearly $19 \%$ of the country's total forest area (General Directorate of Forestry, 2016). In spite of the importance of this species, only a few studies concerning the prediction systems based on site index model exist. Therefore, the aim of this study was to develop the GADA-based dynamic site index models for the Crimean Pine stands located in SarikayaCankiri Forests, Middle Northern TURKEY.

Revista Árvore. 2018;42(3):e420311 


\section{MATERIALS AND METHODS}

\subsection{MATERIALS}

The data for this study are 153 sample trees obtained by $\mathrm{Akba}^{\circ}$ (2017) from the Crimean Pine stands located within Sarikaya Planning unit of the Cankiri Forestry Management Directorate at the Ankara Regional Forestry Directorate, latitude $40^{\circ} 47^{\prime} 3^{\prime \prime}$ and longitude $33^{\circ} 53^{\prime}$ 55" (Figure 1). The data for this study came from Crimean Pine stands in even-aged, pure and natural Scots pine stands. The study area is with low to steep $(10 \%$ to $20 \%$ ) slopes, and the elevation ranges from $900 \mathrm{~m}$ to $1150 \mathrm{~m}$ above sea level. The climate is typical Central Anatolia climate defined by cold winters and hot summers. The mean monthly temperature is from $-15.8^{\circ} \mathrm{C}$ to 28.6 ${ }^{\circ} \mathrm{C}$, minimum and maximum temperatures are $-17.2^{\circ} \mathrm{C}$ and $32.4{ }^{\circ} \mathrm{C}$, respectively, mean annual precipitation is from $450 \mathrm{~mm}$ to $600 \mathrm{~mm}$, and precipitations are distributed relatively homogeneously throughout the year (Meteorological Service, 2005)

These trees were subjectively sampled to represent the range of site qualities and ages variability throughout these Crimean pine stands. Total tree height ranged between 6.0 and $20.5 \mathrm{~m}$, with an average of $13.30 \mathrm{~m}$; tree age ranged between 21 and 170 years, with an average of 95 years. These trees for stem analysis were felled, and also the cross-sectional cuts were made at the first $0.3 \mathrm{~m}$ and the second $1.3 \mathrm{~m}$ of the stem and every $2 \mathrm{~m}$ throughout the tree stem. The number of rings was counted at each cross-sectioned point, and then these values were converted to stumpage, which can be considered equal to tree age. The number of rings at each cross-section was subtracted from the age of the trees at the time they were cut, in order to calculate the time, it took for the trees to reach the height of the relevant cross-sections. Accordingly, the height values of the trees at different ages were determined. The heights in at each cross-sectioned point of sampling trees were calculated by ISSA method based on height/age data at cross-sectional cuts.

\subsection{METHODS}

In this study, the determination of the site quality and the calculation of the site index was performed using the 'polymorphic method,' which is based on the site index models obtained with the GADA. The three-variable index models $\left(h=f\left(t, t_{0}, h_{0}\right)\right)$, based on the transformation of various basic growth models (Chapman-Richards, Lundqvist, Hossfeld, Schumacher
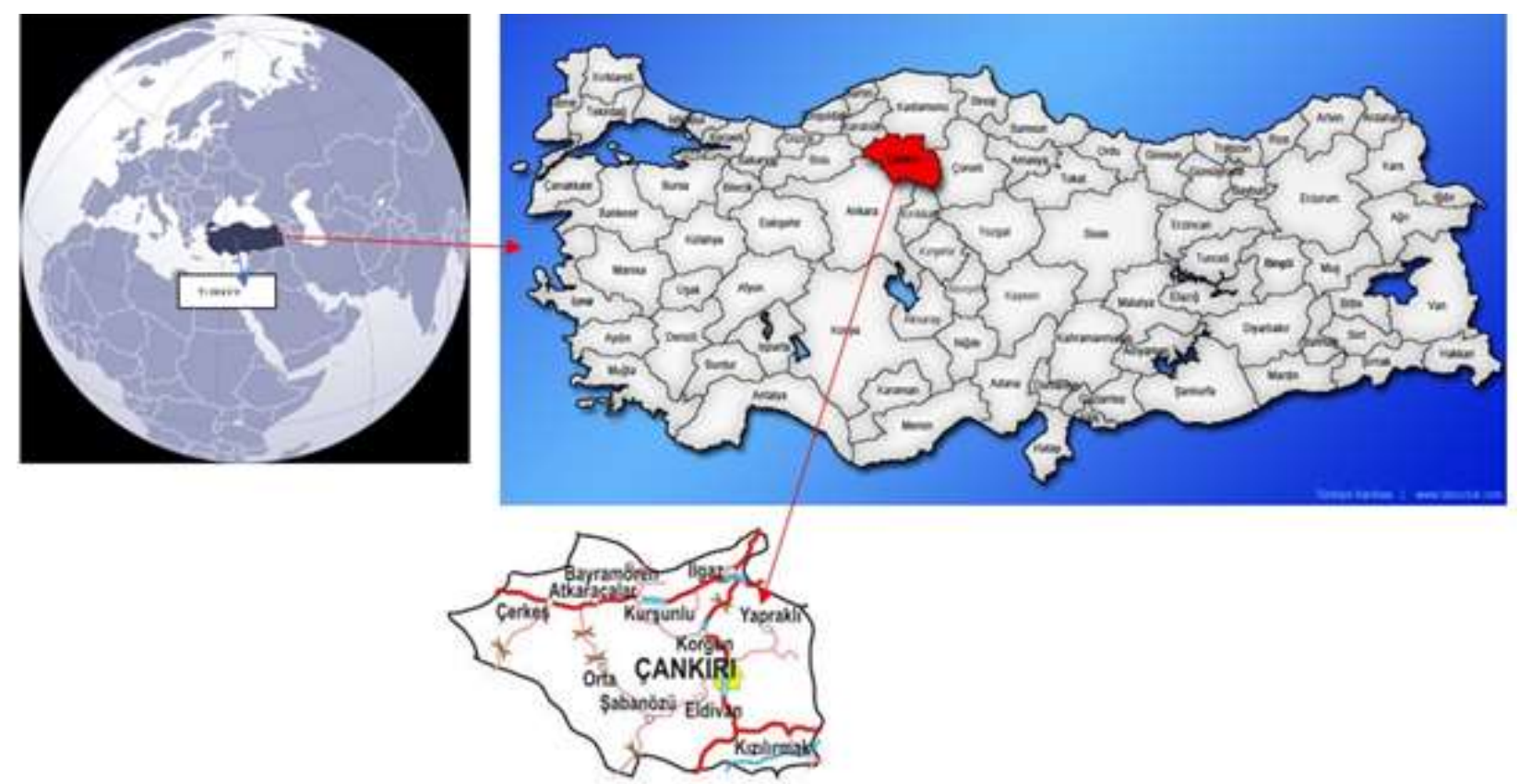

Figure 1 - The study area.

Figura 1 - A área de estudo. 
and Weibull) according to the GADA by Cieszewski (2001, 2002, 2004) and Cieszewski et al. (2008) were employed in this study. These eight functions were transformed by Cieszewski $(2002,2004)$ and Cieszewski at al. (2008) according to the GADA, and thus converted into a model structure that can perform dominant height estimations for a different site and standard ages (100 years).

Table 1 - The dynamic GADA formulations with base models used to model dominant-height growth.

Tabela 1 - As formulações GADA dinâmicas com modelos base usados para modelar o crescimento de altura dominante.

\begin{tabular}{|c|c|c|}
\hline Model & Basic Model & GADA Model \\
\hline$\overline{\mathrm{M} 1}$ & & $\begin{array}{l}h=h_{0}\left(\frac{1-\exp \left(-b_{1} t\right)}{1-\exp \left(-b_{1} t_{0}\right)}\right)^{\left(b_{2}+b_{3} / X_{0}\right)} \\
\mathrm{X}_{0}=\frac{1}{2}\left(\left(\operatorname{Inh_{0}}-b_{2} L_{0}\right)+\sqrt{\left(\operatorname{Inh} h_{0}-b_{2} L_{0}\right)^{2}-4 b_{3} L_{0}}\right) \\
L_{0}=\ln \left(1-\exp \left(-b_{1} t_{0}\right)\right)\end{array}$ \\
\hline M2 & $\begin{array}{l}\text { Chapman-Richards: } \\
\mathrm{h}=\alpha(1-\exp (-\mathrm{bt}))^{\mathrm{c}}\end{array}$ & $\begin{array}{l}h=\exp \left(X_{0}\right)\left(1-\exp \left(-h_{1} t_{0}\right)\right)^{\left(b_{1} l l / X_{0}\right)} \\
\mathrm{X}_{0}=\frac{1}{2}\left(\left(\operatorname{In} h_{0}-h_{2} L_{0}\right)+\sqrt{\left(I n h_{0}-b_{2} L_{0}\right)^{2}-4 L_{0}}\right) \\
L_{0}=\ln \left(1-\exp \left(-b_{1} t_{0}\right)\right)\end{array}$ \\
\hline M3 & & $\begin{array}{l}h=h_{0} \cdot\left[\frac{\left(1-\exp \left(-X_{0} t\right)\right)}{\left(1-\exp \left(-X_{0} \cdot t_{0}\right)\right)}\right]^{b_{3}} \\
\mathrm{X}_{0}=b_{4} \cdot\left(\frac{h_{0}}{t_{0}}\right) \cdot t_{0}^{b_{s}}\end{array}$ \\
\hline M4 & $\begin{array}{c}\text { Lundqvist: } \\
\mathrm{h}=\alpha \cdot \exp \left(-\mathrm{bt}^{-\mathrm{c}}\right)\end{array}$ & $\begin{array}{l}h=\exp \left(X_{0}\right) \exp \left[-\left(b_{1}+\left(\frac{b}{X}\right.\right.\right. \\
X_{0}=\frac{1}{2}\left(b_{1} t_{0}^{-b_{3}}+\ln h_{0}+L_{0}\right) \\
L_{0}=\sqrt{\left(b_{1} t_{0}^{-h_{3}}+\ln h_{0}\right)^{2}+4 b_{2} t_{0}^{-b_{3}}}\end{array}$ \\
\hline M5 & $\begin{array}{l}\text { Hosfeld: } \\
\mathrm{h}=\frac{\mathrm{a}}{1+\mathrm{bt}^{-\mathrm{c}}}\end{array}$ & $\begin{array}{l}h=\frac{\left(b_{1}+X_{0}\right)}{1+b_{2} / X_{0} t^{-b_{3}}} \\
X_{0}=\frac{1}{2}\left(h_{0}-b_{1} \pm \sqrt{\left(h_{0}-b_{1}\right)^{2}-4 b_{2} h_{0} t_{0}^{-h_{3}}}\right)\end{array}$ \\
\hline$\overline{\mathrm{M} 6}$ & $\begin{array}{c}\text { Lundqvist: } \\
\mathrm{h}=\alpha \cdot \exp \left(-\mathrm{bt}^{-\mathrm{c}}\right)\end{array}$ & $\begin{array}{l}h=\exp \left(X_{0}\right) \exp \left[-\left(b_{1}+\left(\frac{b_{2}}{X_{0}}\right)\right) t^{-h_{3}}\right] \\
\mathrm{X}_{0}=\frac{1}{2} \cdot\left(\operatorname{Ln}\left(h_{0}\right)+\sqrt{-\left[\operatorname{Ln}\left(h_{0}\right)\right]^{2}+4 \cdot b_{1} \cdot t_{0}^{b_{3}}}\right)\end{array}$ \\
\hline M7 & $\begin{array}{c}\text { Weibull: } \\
\mathrm{h}=\alpha_{1} \cdot\left(1-\exp \left(-\mathrm{a}_{2} \cdot \mathrm{t}^{\mathrm{a} 3}\right)\right)\end{array}$ & $\begin{array}{l}h=\exp \left[X_{0}+\left[b_{1}+b_{2} \cdot X_{0}\right] \cdot \operatorname{Ln}\left(1-\exp \left(-t^{b_{3}}\right)\right)\right] \\
X_{0}=\frac{\operatorname{Ln}\left(h_{0}\right)-b_{1} \cdot \operatorname{Ln}\left(1-\exp \left(-t_{0}^{b_{3}}\right)\right)}{1+b_{2} \cdot \operatorname{Ln}\left(1-\exp \left(-t_{0}^{b_{3}}\right)\right)}\end{array}$ \\
\hline M8 & $\begin{array}{c}\text { Schumacher: } \\
\mathrm{h}=\exp \left(\mathrm{a}_{1}+\mathrm{a}_{2 .} \mathrm{t}^{\mathrm{a} 3}\right)\end{array}$ & $\begin{array}{l}h=\exp \left(X_{0}-\left(\left(\frac{b_{1}}{X_{0}}\right) \cdot t^{b_{3}}\right)\right) \\
X_{0}=\frac{1}{2}\left(\operatorname{Ln}\left(h_{0}\right)+\sqrt{\left[\operatorname{Ln}\left(h_{0}\right)\right]^{2}-4 \cdot b_{1} \cdot t_{0}^{b_{0}}}\right)\end{array}$ \\
\hline
\end{tabular}

$\mathrm{h}$ and $\mathrm{h} 0$ are dominant height $(\mathrm{m})$ at age $\mathrm{t}$ and t0 (years), $\mathrm{X}$ is the parameter relating site and a, b, c, a1, a2, a3, b1, b2, b3 are fitted regression parameters.

Revista Árvore. 2018;42(3):e420311 
These eight equation structures relating to the three different GADA models used in the study are shown in Table 1.

To determine the equation that is the best predictive in modeling the age-dominant height relations of trees among the different equations developed in this study, the Sum of Squared Error (SSE), the Mean Squared Error (MSE), the Root-Mean-Square-Error(RMSE), Bias and the Adjusted Coefficient of Determination $\left(\mathrm{R}^{2}\right)$ were used. Of these statistical values, it is desirable for the SSE, EMS and RMSE to be as small as possible, while the Adjusted Coefficient of Determination should be as close as possible to 1 . The formulae for these statistical criteria are provided below.

$$
\operatorname{Bias}=\frac{\sum_{i=1}^{n}\left(\mathrm{~h}_{\mathrm{i}}-\widehat{\mathrm{h}_{1}}\right)}{n}
$$

Mean Squared Error $(\mathrm{MSE})=\frac{\sum_{i=1}^{n}\left(h_{\mathrm{i}}-\widehat{\mathrm{h}_{1}}\right)^{?}}{n}$ Eq2

Root - Mean - Square Error $($ RMSE $)=$

$\sqrt{\frac{\sum_{i-1}^{n}\left(h_{i}-\widehat{h_{1}}\right)^{2}}{\mathrm{n}-\mathrm{p}}}$

$$
\text { Sum of Squared Error }(S S E)=\sum_{i=1}^{n}\left(h_{i}-\widehat{\mathrm{h}_{1}}\right)^{2}
$$

Adjusted Coefficient of Determination

$$
\left(R_{\text {adj }}^{2}\right)=1-\frac{\sum_{\mathrm{i}=1}^{\mathrm{n}}\left(h_{\mathrm{i}}-\widehat{h_{1}}\right)^{2}(\mathrm{n}-1)}{\sum_{\mathrm{i}=1}^{\mathrm{n}}\left(h_{\mathrm{i}}-\overline{h_{\mathrm{i}}}\right)^{2}(\mathrm{n}-\mathrm{p})}
$$

The estimations for these eight-dynamic site index model parameters with well as various statistical values were determined using the MODEL procedure of the SAS Statistical Package Software (SAS, 2014).

After determination of the best predictive model, $\operatorname{ARMA}(1,1)$ autoregressive prediction technique was used to account autocorrelation problems for timeseries height measurements. Also, Durbin-Watson statistics was used to evaluate autocorrelation problem. These statistics were obtained by adding \%AR1 and $\%$ MA1 code to MODEL procedure in SAS software.

In further assessment for the best predictive model, the residuals against predicted height values and predicted height values against observed height values were presented.

\section{RESULTS}

The predictions of parameters obtained through autoregressive modeling for the eight dynamic site index models that were used for developing the site index models, as well the various statistical success criteria for these models, are shown in Table 2. Most of the parameters for these tested site index models were determined to be statistically significant with a $p$-value of $<0.05$. The adjusted coefficient of determination values for the obtained equations varied from 0.4435 to 0.8903 ; the MSE values varied from 1.7633 to 8.9491 ; the RMSE values varied from 1.3279 to 2.9915 , and the SSE values varied from 1,165.6 to 5,933.3, Bias varied from -0.0165 to -1.5778 .

An evaluation of the success criteria for the models revealed that the most successful modeling for the dominant height-age relationship was growth function (M3) of Chapman-Richards. The adjusted coefficient of determination for the Chapman-Richards function was 0.8903 , while MSE was 1.7633, RMSE was 1.3279 , SSE was 1165.6, Bias was -0.0380. When ARMA autoregressive prediction technique was applied to the Chapman-Richards function for solving autocorrelation problem, these success statistics were improved as SSE: 868.7, MSE: 1.3183, RMSE: 1.1482, Bias: -0.06369, R2: 0.918. Also, Durbin-Watson statistics displayed that autocorrelation problem was solved by the use of ARMA autoregressive prediction technique; $\mathrm{DW}$ test value $=1.99, \mathrm{DW}<\mathrm{P}=0.5622, \mathrm{DW}>\mathrm{P}=0.4378$. The model structure of the Chapman-Richards equation based on $\operatorname{ARMA}(1,1)$ autoregressive prediction technique is shown below.

$h=h_{0} \cdot\left[\frac{\left(1-\exp \left(-X_{0} \cdot t\right)\right)}{\left(1-\exp \left(-X_{0} \cdot t_{0}\right)\right)}\right]^{1.583763}$

$X_{0}=1.184352 \cdot\left(\frac{h_{0}}{t_{0}}\right)^{-0.48803} \cdot t_{0}^{-1.02081}$

In this equation and model, $h$ represents the estimated dominant height for a certain age $t, t 0$ represents the standard age; and h0 represents the dominant height value for the to standard age.

The compatibility of the height development values obtained with the site index model based on the ChapmanRichards equation with the growth laws used in ageheight relations (and associated with yield strength) 
Table 2 - Parameter estimations and goodness-of-fit statistics of candidate models

Tabela 2 - Estimações de parâmetros e estatísticas de adequação dos modelos candidatos.

\begin{tabular}{|c|c|c|c|c|c|c|c|c|c|c|}
\hline$\overline{\text { Model }}$ & SSE & MSE & RMSE & Bias & $\mathrm{R}_{\text {adj }}^{2}$ & Parameter & Estimate & S.E. & t-Value & $\overline{\mathrm{P}}$ \\
\hline \multirow[t]{3}{*}{ M1 } & 1289.1 & 1.9473 & 1.3955 & -0.0165 & 0.8789 & $\mathrm{~b}_{1}$ & 0.015301 & 0.00120 & 12.74 & $<0.0001$ \\
\hline & & & & & & $b_{2}$ & 1.863891 & 0.2059 & 9.05 & $<0.0001$ \\
\hline & & & & & & $b_{3}$ & -2.1983 & 0.6014 & -3.65 & $<0.0003$ \\
\hline \multirow[t]{2}{*}{ M2 } & 2214.7 & 3.3404 & 1.8277 & 0.0862 & 0.7923 & $b_{1}$ & 0.024206 & 0.00148 & 16.38 & $<0.0001$ \\
\hline & & & & & & $b_{2}$ & 0.821012 & 0.0824 & 9.97 & $<0.0001$ \\
\hline \multirow[t]{4}{*}{ M3 } & 1165.6 & 1.7633 & 1.3279 & -0.0380 & 0.8903 & $\mathrm{~b}_{3}$ & 1.489082 & 0.0846 & 17.61 & $<0.0001$ \\
\hline & & & & & & $\mathrm{b}_{4}$ & 0.793297 & 0.2156 & 3.68 & $<0.0003$ \\
\hline & & & & & & $b_{5}$ & -0.52157 & 0.0982 & -5.31 & $<0.0001$ \\
\hline & & & & & & $\mathrm{b}_{6}$ & -0.97059 & 0.0812 & -11.96 & $<0.0001$ \\
\hline \multirow[t]{3}{*}{ M4 } & 1223.3 & 1.8478 & 1.3594 & 0.0315 & 0.8851 & $b_{1}$ & 14.53492 & 1.4134 & 10.28 & $<0.0001$ \\
\hline & & & & & & $b_{2}$ & -23.132 & 4.9165 & -4.71 & $<0.0001$ \\
\hline & & & & & & $b_{3}$ & 0.428683 & 0.0390 & 10.99 & $<0.0001$ \\
\hline \multirow[t]{3}{*}{ M5 } & 4337 & 6.5513 & 2.5596 & -0.1065 & 0.5926 & $\mathrm{~b}_{1}$ & 27346946 & 31039022 & 0.88 & $0.3786^{\mathrm{ns}}$ \\
\hline & & & & & & $\mathrm{b}_{2}$ & 0.015371 & 0.00260 & 5.92 & $<0.0001$ \\
\hline & & & & & & $\mathrm{b}_{3}$ & -0.41904 & 0.0195 & -21.51 & $<0.0001$ \\
\hline \multirow[t]{2}{*}{ M6 } & 1742.8 & 2.6287 & 1.6213 & -0.0351 & 0.8365 & $b_{1}$ & 487106 & 4139518 & 0.12 & $0.9064^{\mathrm{ns}}$ \\
\hline & & & & & & $\mathrm{b}_{3}$ & 0.00099 & 0.00419 & 0.24 & $0.8135^{\mathrm{ns}}$ \\
\hline \multirow[t]{3}{*}{ M7 } & 1244.5 & 1.880 & 1.3711 & 0.0279 & 0.8831 & $\mathrm{~b}_{1}$ & 15.1457 & 0.8577 & 17.66 & $<0.0001$ \\
\hline & & & & & & $b_{2}$ & 0.242165 & 0.00969 & 24.98 & $<0.0001$ \\
\hline & & & & & & $b_{3}$ & -0.2854 & 0.1254 & -2.28 & $<0.0232$ \\
\hline \multirow[t]{2}{*}{ M8 } & 5933.3 & 8.9491 & 2.9915 & -1.5778 & 0.4435 & $\mathrm{~b}_{1}$ & 9.316315 & 0.9234 & 10.09 & $<0.0001$ \\
\hline & & & & & & $\mathrm{b}_{3}$ & -0.71343 & 0.0273 & -26.16 & $<0.0001$ \\
\hline
\end{tabular}

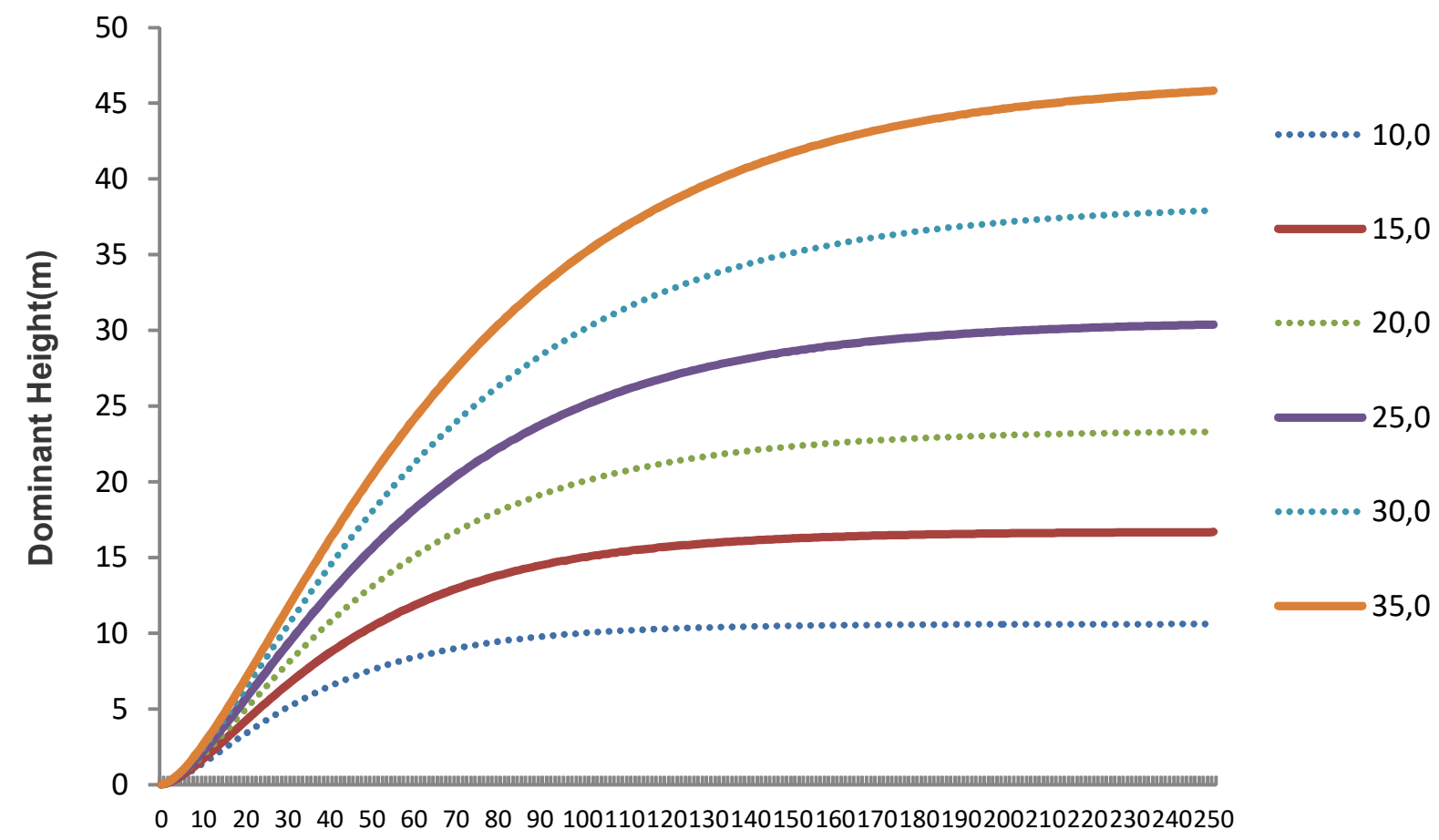

Age (Years)

Figure 2 - The site index curves generated with GADA to 250 years.

Figura 2 - As curvas de índice do site geradas com o GADA para 250 anos.

Revista Árvore. 2018;42(3):e420311 

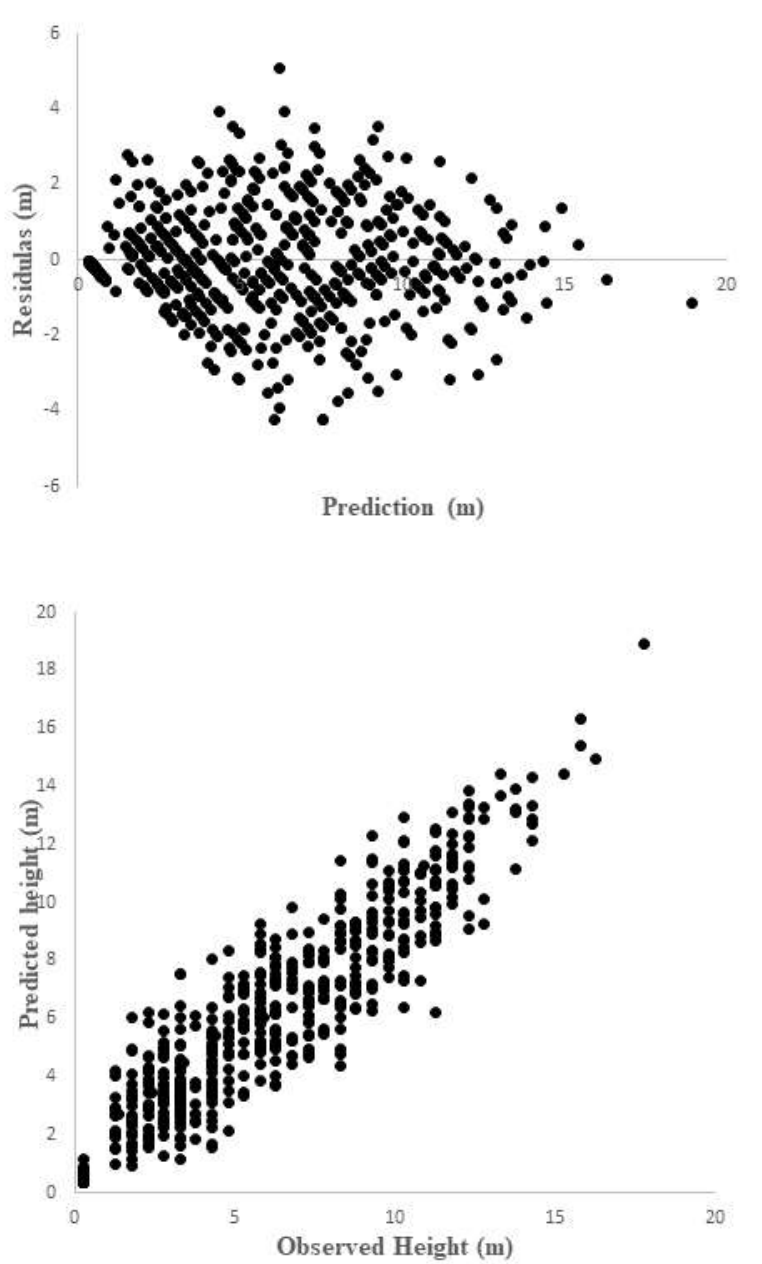

Figure 3 - The residuals against predicted height values (a) and predicted height values against observed height values for the Chapman-Richards' equation.

Figura 3 - Os residuos contra os valores de altura previstos (a) e os valores de altura previstos em relação aos valores de altura observados para a equação de Chapman-Richards.

was evaluated. The characteristics that are expected in age-dominant height relation according to the site index modeling that was taken into account during the evaluation process (the growth laws) include basic characteristics such as polymorphism, multiple asymptotes, the Sigmoidal trend of curves, and the decrease in the time for reaching maximum height. The growth graphs relating to the dominant height-age relations - used for evaluating the mentioned characteristics of the Chapman-Richards model based on $\operatorname{ARMA}(1,1)$ autoregressive prediction technique
- are shown in Figure 2 for 250 years. An evaluation of Figure 2 reveals that the age-dominant height relations obtained with the Chapman-Richards model are compatible with the expected growth laws mentioned above. In other words, the obtained site index values (Figure 2) exhibit multiple asymptotes and an S-shaped curve, whose trend varies according to the site index values (polymorphism).

Figure 3 shows the residuals against predicted height values (a) obtained by the Chapman-Richards' equation based on $\operatorname{ARMA}(1,1)$ autoregressive prediction technique and the predicted height values based on $\operatorname{ARMA}(1,1)$ autoregressive prediction technique against observed values (b). The Chapman-Richards' equation presented random outlines of residual around zero and no obvious signs. Thus, there is no serious failure of homoscedasticity, violations of the assumption of constant variance, in the Chapman-Richards' equation.

\section{DISCUSSION}

In this study, 153 dominant and co-dominant trees were felled from stands in Sarikaya Planning unit of the Cankiri Forests and carried out some stem analysis in order to developed site index models. In the modeling of dominantage height relations, three variable dynamic site index equations $(\mathrm{h}=\mathrm{f}(\mathrm{t}, \mathrm{t} 0, \mathrm{~h} 0)$, developed based on the conversion of the Chapman-Richards (M1, M2 and M3), Lundqvist (M4 and M6), Hossfeld (M5), Weibull (M7) and Schumacher(M8) according to the GADA Cieszewski $(2001,2002,2004)$ and Cieszewski et. al. (2008) were utilized. Of these equations, the Chapman-Richards equation (M3) had an explanatory power of $89.03 \%$ in the modeling of dominant-age height relations and was found to be the most successful model.

The GeneralizedAlgebraic DifferenceApproach(GADA) is being increasingly preferred in recent years for the development of site index models in the literature. The studies of Cieszewski (2001, 2002, 2003); Cieszewski and Nigh (2002); Trincado et al. (2003); Diéguez-Aranda et al. (2005, 2006); Nord-Larsen (2006); Adame et al. (2006); BravoOviedo et al. (2007); Cieszewski et al. (2007) and Cieszewski and Strub (2008) can be mentioned as examples of studies developing site index models with the GADA. Site index models obtained with the GADA approach are especially successful in meeting the requirements of all laws/principles concerning growth and the expected relations between age and height. In this study, the Schumachermodel was determined as the most successful; the dominant height-age relations observed with this model had polymorphism and multiple

Revista Árvore. 2018;42(3):e420311 
asymptotes for different site index values, and its trends were compatible with the basic and laws on growth that are expected in the modeling of dominant height-age relations.

In addition to these characteristics of the site index models that were compatible with the growth laws, another important feature of these models was that they contained the two independent variables $\mathrm{t} 0$ and $\mathrm{h} 0$ in addition to the age (a characteristic granted by the GADA to site index models). These two variables, which are standard age (t0) and the site index indicator (h0), allow site index models to estimate dominant heights for different standard ages and site index, by using a single model. While the standard age was considered as 100 years in this study, it was possible to assign other ages such as 50,75 and 30 to the to variable in order to obtain dominant height estimations for different standard ages. In classical site index methods, the models are developed - and the estimations are obtained - according to a standard age, and it is not possible to make estimations for other standard ages. On the other hand, in the dynamic site index models developed with the GADA, it is possible to make estimations for different standard ages by using a single model structure. Furthermore, the GADA provides the ability to estimate site index for different standard ages by using the site index curve and does not require, at first, the selection of a standard age during the development of the model. The site index models concerning the GADA are also designated as "base-age invariable models," in that their estimations do not vary according to the standard age. In addition, this invariability with regards to the standard age also describes the fact that the estimated height (h) for a certain age does not vary when different standard age value (different t 0 values) is employed. Base-age invariability also grants GADA-based site index models with the feature of not having their estimated height value (h) change according to any time $t$ regardless of the use of different standard ages on the site index curve.

The GADA allows the development of models that enable the more accurate and consistent determination of the site index values in which local tree species in Turkey are distributed, and there is a significant need for such GADA-based dynamic site index models. Furthermore, to increase the estimation consistency and validity of site index models, it is important to form permanent sample plots that will represent the different sites and stands, and which will allow periodic measurements to be performed. Models that will be developed with the aid of permanent sample plots will not only increase the estimation consistency and validity of the models but will also enable researchers to monitor the suitability of these models at different time periods and to update them when necessary.

\section{ACKNOWLEDGEMENTS}

This study is a part of a master science thesis prepared by Akbas (2017) for the Institute of Natural and Applied Science, Cankiri Karatekin University, Cankiri, Turkey. We would like thanks to Institute of Natural and Applied Science of Cankiri Karatekin University Department for their assistance and ideas.

\section{REFERENCES}

Adame P, Cañellas I, Roig S, del Rio M. Modeling dominant height growth and site index curves for Rebollo oak (Quercus pyrenaica Willd.) Ann For Sci. 2006;63:929-40.

Akbas U. Developing dynamic site index models for Black Pine [Pinus nigra arnold. subsp. pallasiana (lamb.) holmboe] stands in Sarýkaya Forest Enterprise [thesis]. Çankiri Karatekin University Natural And Applied Science; 2017.

Hirigoyen A, Franco J, Dieguez U. Modelo dinámico de rodal para Eucalyptus globulus (L.) en Uruguay. Agrociencia Uruguay, 2018;22(1):63-80.

Bailey RL, Clutter JL. Base-Age invariant polymorphic site curves. Forest Science. 1974;20:155-9.

Bravo-Oviedo A, del Río M, Montero G. Geographic variation and parameter assessment in generalized algebraic difference site index modeling. Forest Ecology and Management. 2007;247(1-3):107-19.

Carmean WH. Site index curves for upland oaks in The Central States. Forest Science. 1972;18:109-20.

Cieszewski CJ. Three methods of deriving advanced dynamic site equations demonstrated on inland douglas-fir site curves. Canadian Journal of Forest Research. 2001;31:165-73.

Cieszewski CJ. Comparing fixed and variablebase-age site equations having single versus multiple asymptotes. Forest Science. 2002;48(1):7-23. 
Cieszewski CJ. Developing a well-behaved dynamic site equation using a modified hossfeld IV Function $\mathrm{Y}^{3}=\left(\mathrm{Ax}^{\mathrm{m}}\right) /\left(\mathrm{C}+\mathrm{X}^{\mathrm{m}-1}\right)$, A simplified mixed-model and scant subalpine fir data. Forest Science. 2003;49(4):539-54.

Cieszewski CJ. GADA derivation of dynamic site equations with polymorphism and variable asymptotes from Richards, Weibull, and other exponential functions. Georgia: University of Georgia PMRC-TR; 2004. 16p

Cieszewski CJ, Bailey RL. Generalized algebraic difference approach: Theory based derivation of dynamic site equations with polymorphism and variable asymptotes, Forest Science. 2000;46:1 16-26.

Cieszewski CJ, Nigh G. A dynamic equation for a Sitka Spruce height-age model. Forest Chronicle. 2002;78(5):1-5.

Cieszewski CJ, Strub M. Generalized algebraic difference approach derivation of dynamic site equations with polymorphism and variable asymptotes from exponential and logarithmic functions. Forest Science. 2008;54:303-15.

Cieszewski CJ, Strub M, Zasada MJ. New dynamic site equation that fits best the schwappach for Scots Pine (Pinus Slyvestris L.) in Central Europe. Forest Ecology and Management. 2007;23:83-93.

Clutter JL, Fortson JC, Peinar LV, Brister GH, Bailey RL. Timber management-A quantitative approach. New York: Wiley; 1983. p.333.

Curtis RO, DeMars DJ, Herman FR. Which dependent variables in site index-height-age regressions?. Forest Science. 1974;20:74-87.

Diéguez-Aranda U, Grandas-Arias JA, ÁlvarezGonzález JG, Gadow KV. Site quality curves for birch stands i north-western Spain. Silva Fennica. 2006;40(4):631-44.

Diéguez-Aranda U, Burkhart HE, RodriguezSoalleiro R. Modeling dominant height growth of radiata pine (Pinus radiata $\mathrm{D}$. Don) plantations in north-western Spain. Forest Ecology and Management. 2005;215:271-84.

Elfving B, Kiviste A. Construction of site index equations for Pinus sylvestris L. using permanent plot data in Sweden. Forest Ecology Management. 1997;98:125-34.

General Directorate of Forestry Plant. 2016.

Kahriman A, Sönmez T, Gadow KV. Site index models for Calabrian pine in the central Mediterranean region of Turkey. Journal of Sustainable Forestry. 2018;37(5):459-74.

Kalipsiz A. Forest yield studies. Ýstanbul: Istanbul University Faculty of Forestry; 1998.349.p (Publications, Number:4060/448)

Liziniewicz M, Nilsson U, Agestam E, Ekö PM, Elfving B. A site index model for lodgepole pine (Pinus contorta Dougl. var. latifolia) in northern Sweden. Scandinavian Journal of Forest Research. 2016;31(6):583-91.

López-Sánchez CA, Álvarez-González JG, Diéguez-Aranda U, Rodríguez-Soalleiro R. Modelling dominant height growth in plantations of Pseudotsuga menziesii (Mirb.) Franco in Spain. Southern Forests. 2015;77(4):315-9.

Monserud RA. Height growth and site index curves for inland douglas-fir based on stem analysis data and forest habitat type. Forest Science. 1984;30:943-65.

Nigh G. Development of a lodgepole pine site index model with the grounded Generalized Algebraic Difference Approach (g-GADA). Victoria: British Columbia Research; 2017.

Nord-Larsen T. Developing dynamic site index curves for European beech (Fagus sylvatica L.) in Denmark. Forest Science. 2006;52:173-81.

Pyo J. Developing the site index equation using a generalized algebraic difference approach for Pinus densiflora in central region, Korea. Forest Science and Technology; 2017;13(2):87-91.

Ribeiro A, Ferraz Filho AC, Tomé M, Scolforo JRS. Site quality curves for african mahogany plantations in Brazil. Cerne. 2016;22(4):439-48.

Rodríguez-Carrillo A, Cruz-Cobos F, Vargas-Larreta B, Hernández FJ. Compatible dominant height-site 
index model for juniper (Juniperus deppeana Steud.). Revista Chapingo. Serie Ciencias Forestales y del Ambiente. 2015;21(1):97-108.

SAS Institute Inc. SAS/ETS ${ }^{2} 9.1$ User's Guide. Cary, NC: 2014.

Seki M, Sakici OE. Dominant height growth and dynamic site index models for Crimean pine in the Kastamonu-Tas, köprü region of Turkey. Canadian Journal Foresty Research. 2017;47:1441-9.

Stage AR. A mathematical approach to polymorphic site index curves for grand fir.
Forest Science. 1963;9:167-80.

Tewari VP, Álvarez-González JG, von Gadow K. Dynamic base-age invariant site index models for Tectona grandis in peninsular India. Southern Forests. 2014;76:21-7.

Trincado GV, Kiviste A, Gadow KV. Preliminary site index models for native Roble (Nothofagus obliqua) and Rauli (N. Alpina) in Chile. New Zealand Journal of Forestry Science. 2003;32(3):322-33.

Turkish .Meteorological Service, 2005.

Revista Árvore. 2018;42(3):e420311 